\title{
RESPON PERTUMBUHAN BIBIT BAMBANG LANANG (Michelia champaca L.) TERHADAP CEKAMAN
}

\author{
Growth Respon of Bambang Lanang Seedling (Michelia champaca L.) to Stress Condition \\ Yulianti Bramasto ${ }^{1}$, Evayusvita Rustam ${ }^{1}$, Megawati ${ }^{1}$, Nina Mindawati ${ }^{2}$ \\ ${ }^{1}$ Balai Penelitian Teknologi Perbenihan Tanaman Hutan \\ Jl. Raya Ciheuleut, Po Box. 105 Bogor 16001, Jawa Barat, Indonesia \\ Telp./Fax. +62-251-8327768 \\ ${ }^{2}$ Pusat Penelitian dan Pengembangan Hutan \\ Kampus Badan Litbang dan Inovasi \\ Jl. Gunung Batu No.5 Kotak Pos 15, Bogor 16118, Jawa Barat, Indonesia \\ Telp. +62-251-8633234, Fax. +62-251-8638111 \\ Email: yuli_bramasto@yahoo.co.id ${ }^{1}$,ninapulp@yahoo.co.id ${ }^{2}$
}

Tanggal diterima: 23 Januari 2015; Tanggal direvisi: 16 Oktober 2015; Tanggal disetujui: 26 Oktober 2015

\begin{abstract}
Climate change has caused some part of land in Indonesia become waterlogged or drought. One approach of mitigation is to find out adaptive species in such condition. However the knowledge about growth capability of bambang lanang in waterlogged or drought stress is very limited. The objective of this research was to know the growth responses of bambang lanang seedlings on waterlogged or drought stress. Research design used was Factorial in Randomized Complete Design. The results showed that seedling of bambang lanang until four weeks old was sensitive to drought or waterlogged treatment, as confirmed by IS for diameter response and survival rate of 1.089-1.155 and 1.318, respectively. In general tolerant mechanism for stress condition is not been visible at the seedling level until four weeks old.
\end{abstract}

Keywords: Drought, Michelia champaca, growth, waterlogged

\begin{abstract}
ABSTRAK
Perubahan iklim menyebabkan sebagian lahan di Indonesia menjadi tergenang ataupun kekeringan. Salah satu bentuk mitigasi yang dapat dilakukan adalah mengetahui jenis-jenis tanaman yang mampu tumbuh pada kondisi cekaman tergenang atau kekeringan. Informasi tentang kemampuan tumbuh bambang lanang pada berbagai kondisi cekaman masih sangat kurang. Penelitian ini bertujuan untuk mengetahui respon pertumbuhan bibit bambang lanang pada kondisi cekaman tergenang dan kekeringan. Rancangan penelitian yang digunakan adalah rancangan faktorial dalam acak lengkap. Hasil penelitian menunjukkan bahwa bibit bambang lanang sampai umur empat minggu, peka terhadap perlakuan kekeringan ataupun genangan. Kematian pada bibit terlihat dari nilai indeks sensitivitas untuk respon diameter (IS = 1,089-1,155) dan persen tumbuh (IS =1,318). Secara umum mekanisme toleran terhadap cekaman belum terlihat pada tingkat bibit sampai umur empat minggu.
\end{abstract}

Kata kunci: Kekeringan, Michelia champaca, pertumbuhan, tergenang

\section{PENDAHULUAN}

Bambang lanang (Michelia champaca L.) termasuk dalam famili Sapotaceae adalah jenis asli Indonesia yang potensial. Jenis ini sudah mulai dikembangkan di hutan rakyat khususnya di daerah Sumatera Selatan (Kunarso \& Siahaan, 2008). Jenis ini merupakan jenis tanaman hutan penghasil kayu pertukangan, dan telah lama digunakan sebagai bahan bangunan oleh masyarakat setempat karena kayunya yang kuat dan awet. Secara tradisional petani telah membudidayakan kayu bambang lanang dengan motivasi awal untuk memenuhi konsumsi kayu pertukangan bagi keluarga. Saat ini bambang lanang sudah dikembangkan lebih luas karena secara ekonomis kayunya mempunyai harga yang cukup baik. Tanaman bambang lanang tumbuh pada ketinggian antara 600-2.000 m dpl, namun dapat dijumpai juga pada ketinggian yang lebih rendah, dengan suhu rata-rata tahunan berkisar antara $7^{0}-38^{\circ} \mathrm{C}$ (Orwa et al., 2009). 
Program pengembangan hutan tanaman tidak hanya diperlukan untuk tapak-tapak yang optimal tetapi juga untuk mengembangkan pohonpohon yang cocok untuk tapak-tapak marjinal. Kompetisi penggunaan lahan yang terus meningkat dan menurunnya kualitas lahan di beberapa lokasi telah memaksa operasional kehutanan bergeser dari lahan produktif ke lahan marjinal. Marjinalitas lahan juga akan semakin meningkat dengan adanya fenomena perubahan iklim yang mempengaruhi kondisi cuaca secara ekstrim yang berdampak pada timbulnya ancaman kekeringan dan banjir pada sebagian wilayah Indonesia (Tim Sintesis Kebijakan, 2008). Beberapa kawasan hutan tanaman industri yang dikelola oleh HPHHTI, sebagian lahannya merupakan lahan yang kadang-kadang mengalami genangan, sehingga diperlukan informasi jenis-jenis tanaman yang tahan terhadap kondisi ini. Apabila kondisi ini tidak diantisipasi, maka hal ini akan mengancam keberhasilan kegiatan penanaman. Selain itu, berdasarkan prediksi adanya pemanasan global akan memicu peningkatan kekeringan yang akan mempengaruhi keberhasilan penanaman. Oleh karena itu, perlu mempertimbangkan hubungan toleransi tanaman terhadap kekeringan maupun genangan. Sebagai langkah awal dilakukan penelitian pada tingkat bibit untuk mengetahui ketahanan terhadap cekaman dengan berdasarkan respon pertumbuhan akibat perlakuan simulasi cekaman. Hal ini berkaitan dengan upaya mendapatkan bentuk mitigasi tanaman terhadap perubahan iklim global. Beberapa hasil penelitian yang berkaitan dengan dampak cekaman pada tanaman telah banyak dilaporkan, baik dari kelompok tanaman angiospermae maupun gymnospermae. Adanya kondisi cekaman air baik kekeringan maupun genangan pada tanaman dapat menyebabkan adanya pengaruh terhadap proses fisiologi, morphologi serta biokimia (Cernusak et al., 2007; Chaves et al., 2008; Cordeiro et al., 2009; Ditmarova et al. 2009; Yang \& Miao 2010; Li et al., 2011; Xioling et al., 2011). Pemanfaatan jenis-jenis potensial seperti bambang lanang untuk dikembangkan di hutan tanaman menjadi pilihan untuk mengantisipasi kondisi di lahan ekstrim, namun informasi kemampuan adaptasi dari jenis ini masih terbatas. Oleh karena itu tujuan penelitian ini adalah untuk mengetahui respon pertumbuhan bibit bambang lanang akibat perlakuan cekaman genangan maupun kekeringan.

\section{METODOLOGI}

\section{A. Lokasi Penelitian}

Kegiatan pengujian dan pengamatan dilaksanakan di Laboratorium Balai Penelitian Teknologi Perbenihan Bogor. Pengambilan benih dilakukan di Kabupaten Lahat, Sumatera Selatan.

\section{B. Bahan dan Alat}

Bahan yang digunakan dalam penelitian ini adalah benih bambang lanang, dan berbagai peralatan yang digunakan untuk perkecambahan benih serta pembibitan, meliputi wadah perkecambahan, media perkecambahan, wadah bibit serta media bibit.

\section{Prosedur Kerja}

\section{Persiapan bibit dan rancangan penelitian}

Benih dari setiap populasi ditaburkan pada media campuran tanah dan pasir halus $(1: 1 \mathrm{v} / \mathrm{v})$ yang telah disterilkan. Penyiraman dilakukan setiap hari dengan menggunakan sprayer. Setelah kecambah berukuran 3-5 cm, dipindahkan ke dalam pot berukuran diameter $20 \mathrm{~cm}$ dan tinggi $21 \mathrm{~cm}$ dengan media top soil. Bibit dipelihara sampai terlihat kokoh, setelah itu perlakuan beragam kondisi air media dilakukan. Bibit untuk perlakuan "selalu tergenang" diletakkan dalam kolam buatan yang selalu terisi air, bibit dengan perlakuan kekeringan diletakkan dalam bedeng yang tertutup sungkup, sehingga air hujan tidak dapat masuk, sedangkan untuk kontrol diletakkan pada kondisi normal dan dilakukan penyiraman rutin sesuai kapasitas lapang. Untuk mengetahui kapasitas lapang, terlebih dahulu dilakukan pengukuran kapasitas lapang media yang akan digunakan untuk bibit bambang lanang, sehingga diperoleh nilai kapasitas lapang.

Analisis data untuk respon persen tumbuh, tinggi bibit, diameter bibit dan jumlah daun menggunakan Rancangan Faktorial dalam Rancangan Acak Lengkap, terdiri dari 2 (dua) faktor yaitu faktor waktu pengamatan (minggu 1, minggu 2, minggu 3 dan minggu 4), sebagai faktor cekaman air terdiri dari 3 (tiga) taraf, yaitu: kontrol (bibit disiram setiap hari sesuai kapasitas lapang), bibit selalu tergenang air, dan untuk kondisi kekeringan bibit disiram setiap hari sebanyak 25\% dari kapasitas lapang (25\% KL). Adapun analisis data untuk respon lainnya meng- 
gunakan rancangan acak lengkap, karena pengukuran dilakukan hanya pada akhir pengamatan (minggu ke-4). Masing-masing perlakuan terdiri dari 50 bibit diulang sebanyak 4 kali.

\section{Pengukuran pertumbuhan}

Pengukuran persen tumbuh, tinggi bibit, diameter dan jumlah daun dihitung setiap minggu hingga minggu keempat, sedangkan luas daun dan biomassa diukur pada akhir penelitian atau minggu keempat. Luas daun diukur dengan leaf area meter. Pengukuran biomassa dilakukan dengan mengeringkan seluruh bagian tanaman (akar, batang dan daun) dalam oven selama 48 jam pada suhu $70^{\circ} \mathrm{C}$. Produksi berat kering tanaman total dihitung dengan menjumlahkan berat kering akar, batang dan daun. Rasio pucuk akar (RPA) diukur berdasarkan berat kering pucuk dibagi berat kering akar, rasio luas daun (RLD) untuk masing-masing bibit diukur berdasarkan luas daun total dibagi berat kering bibit, dan luas daun spesifik (LDS) dihitung sebagai luas daun dibagi berat kering daun. Seluruh parameter pertumbuhan tersebut dapat mencerminkan vigoritas bibit.

\section{Pengukuran kadar air relatif daun dan kerapatan stomata}

Kadar air relatif(KAR) ditentukan secara gravimetrik. Tiga daun per bibit diambil contohnya dari bagian tengah kanopi. KAR diukur dengan menimbang bobot segar (bs) yang diukur segera setelah dipanen, setelah itu segera direndam dalam akuades selama 24 jam untuk mendapatkan bobot turgid (bt). Selanjutnya potongan daun dikeringkan dalam oven selama 48 jam pada suhu $70^{\circ} \mathrm{C}$ sehingga mendapat bobot kering (bk). Kadar air relatif dihitung dengan rumus (bsbk)/ (bt-bk)x100\%.

Pengamatan stomata dilakukan terhadap kerapatan stomata daun dengan menghitung jumlah stomata per satuan luas bidang pengamatan dengan cara menghitung jumlah stomata per milimeter persegi $\left(\mathrm{mm}^{2}\right)$ (Suharno et al., 2007), serta diameter dan panjang stomata. Pengamatan stomata pada daun dilakukan pada tiga (3) waktu yang berbeda, yaitu diamati pada pagi hari, siang hari dan sore hari. Oleh karena itu, rancangan percobaan yang digunakan untuk pengamatan stomata adalah Rancangan Faktorial dalam Rancangan Acak Lengkap. Terdapat 2 faktor yaitu cekaman air (terdiri dari tiga taraf yaitu kontrol, tergenang dan kekeringan pada KL 25 $\%$ ) dan waktu pengamatan (terdiri dari 3 taraf yaitu pagi, siang dan sore hari).

\section{Pengukuran kandungan prolin dan serap- an $\mathbf{C}, \mathbf{N}, \mathbf{P}$ dan $\mathrm{K}$}

Untuk mengetahui nutrient up take, yang mampu diserap oleh daun akibat dari kondisi cekaman (genangan dan kekeringan), dihitung melalui analisis kandungan nutrisi pada daun (kandungan N,P,K dan C) serta biomassa kering dari bibit tersebut. Nilai nutrient up take diperoleh berdasarkan hasil perkalian antara kandungan nutrisi dengan biomassa kering. Selain itu, dihitung juga kandungan prolin sebagai respon karena adanya perlakuan cekaman.

\section{Analisis data}

Data dianalisis dengan menggunakan analisis ragam, apabila ada keragaman dilakukan dengan Uji Lanjut menggunakan Duncan's Multiple Range Test (DMRT) taraf uji 5\%. Menurut Lapanjang et al. (2008), untuk menunjukkan ekotipe toleran, agak toleran dan peka terhadap cekaman kekeringan dilakukan pengamatan terhadap indeks sensitivitas (IS). Indeks sensitivitas yang dihitung berdasarkan rumus Fischer \& Maurer (1978) yaitu:

Keterangan (Remarks)

$$
\mathrm{IS}=\frac{\frac{1-\mathrm{Y}}{\mathrm{Yp}}}{\frac{1-X}{X p}}
$$

$(\mathrm{Y})=$ Nilai rataan peubah tertentu pada suatu ekotipe yang mengalami cekaman kekeringan,

$(Y p)=$ Nilai rataan peubah tersebut pada satu ekotipe lingkungan optimum,

$(\mathrm{X})=$ Nilai rataan peubah tersebut pada semua ekotipe yang mengalami cekaman kekeringan,

$(\mathrm{Xp})=$ Nilai rataan peubah tersebut pada semua ekotipe lingkungan optimum.

Ekotipe dikatakan toleran terhadap ceka-man kekeringan jika mempunyai nilai IS $<0,5$; agak toleran $(0,5 \leq \mathrm{IS} \leq 1)$, dan peka (IS $>1)$.

\section{HASIL DAN PEMBAHASAN}

\section{A. Hasil Penelitian}

\section{Pertumbuhan bibit}

Hasil analisis ragam menunjukkan bahwa untuk respon pertumbuhan tinggi dipengaruhi oleh perlakuan cekaman, namun untuk diameter dipengaruhi oleh waktu dan perlakuan. Jumlah daun dan persentase tumbuh bibit dipengaruhi oleh interaksi antara waktu dan perlakuan. Respon pertumbuhan yang menunjukkan adanya keragaman, dilanjutkan dengan Uji Duncan. Hasil uji Duncan untuk tinggi dan diameter dapat dilihat pada Tabel 1. Adapun untuk jumlah daun 
dan persen tumbuh dapat dilihat pada Gambar 1 dan 2.

Hasil uji lanjut (Tabel 1) menunjukkan bahwa pada pertumbuhan tinggi, bibit yang selalu tergenang berbeda nyata dengan kontrol dan cekaman kekurangan air, demikian pula untuk pertumbuhan diameter, bibit yang selalu ter- genang berbeda nyata dengan kontrol, namun tidak berbeda nyata dengan cekaman kekurangan air. Pertumbuhan diameter bibit pada umur empat dan tiga minggu tidak berbeda nyata, namun berbeda nyata dengan bibit pada umur satu dan dua minggu.

Tabel (Table) 1. Hasil Uji Duncan untuk tinggi dan diameter (Duncan's test of height and diameter)

\begin{tabular}{lclc}
\hline Sumber (Source) & Respon (Response) & Sumber (Source) & Respon (Response) \\
\hline Cekaman air (Water stress) & Tinggi (Height) & Waktu (Times) & Diameter (Diameter) \\
\hline Tergenang (Waterlogged) & $31,41 \mathrm{a}$ & Minggu 4 & $4,88 \mathrm{a}$ \\
Kontrol (Control) & $30,26 \mathrm{~b}$ & Minggu 3 & $4,77 \mathrm{ab}$ \\
$25 \%$ KL (25\% water capacity) & $29,61 \mathrm{~b}$ & Minggu 2 & $4,66 \mathrm{bc}$ \\
& & Minggu 1 & $4,60 \mathrm{c}$ \\
\hline & & Cekaman air (Water stress) & Diameter (Diameter) \\
\hline & & Tergenang (Waterlogged) & $5,03 \mathrm{a}$ \\
& & 25\% KL (25\% water capacity) & $5,01 \mathrm{a}$ \\
& & Kontrol (Controle) & $4,22 \mathrm{~b}$ \\
\hline
\end{tabular}

Sumber (Source): Diolah dari data lapang (Compiled and analyzed from field data)

Persen tumbuh

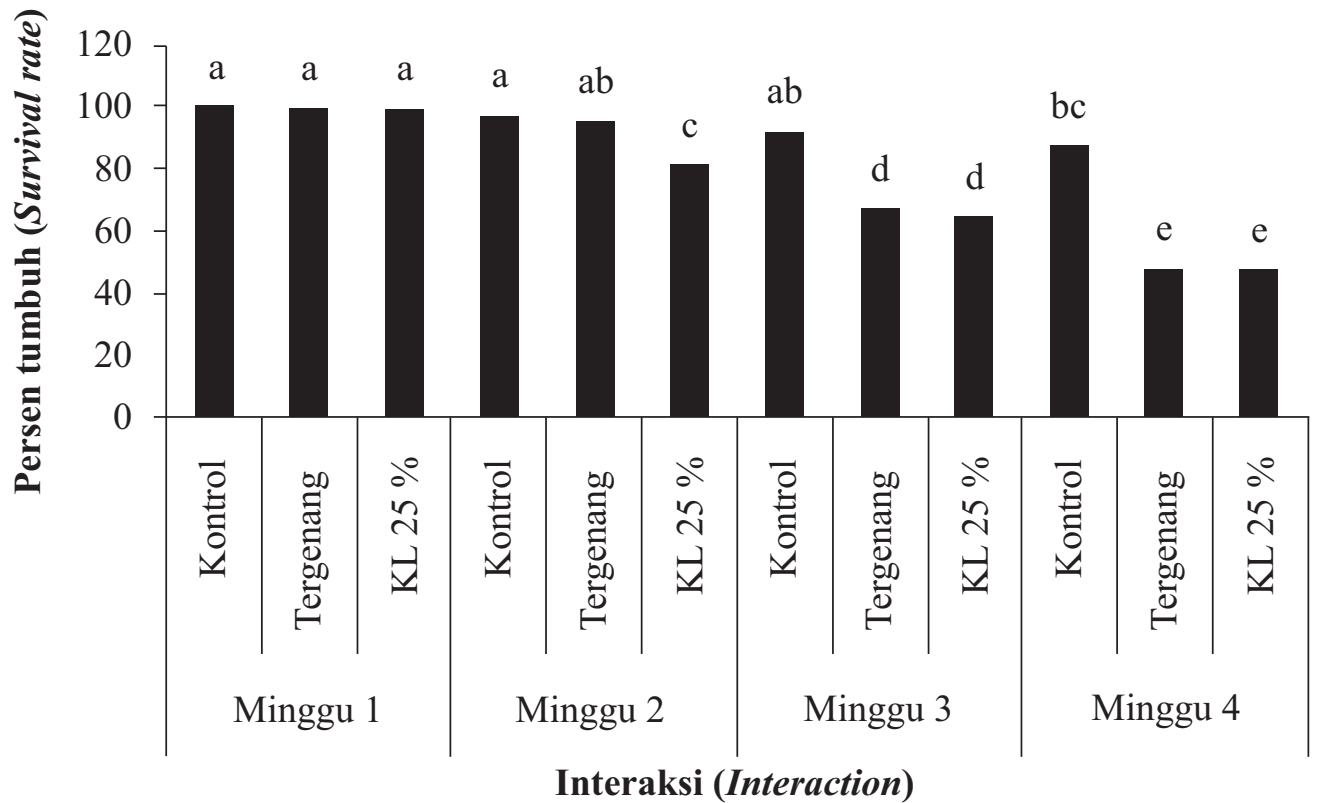

Sumber (Source): Diolah dari data lapang (Compiled and analyzed from field data)

Gambar (Figure) 1. Uji Duncan persen tumbuh berdasarkan interaksi antara waktu dan perlakuan (Duncan' test of survival rate based on interaction between time and treatment) 


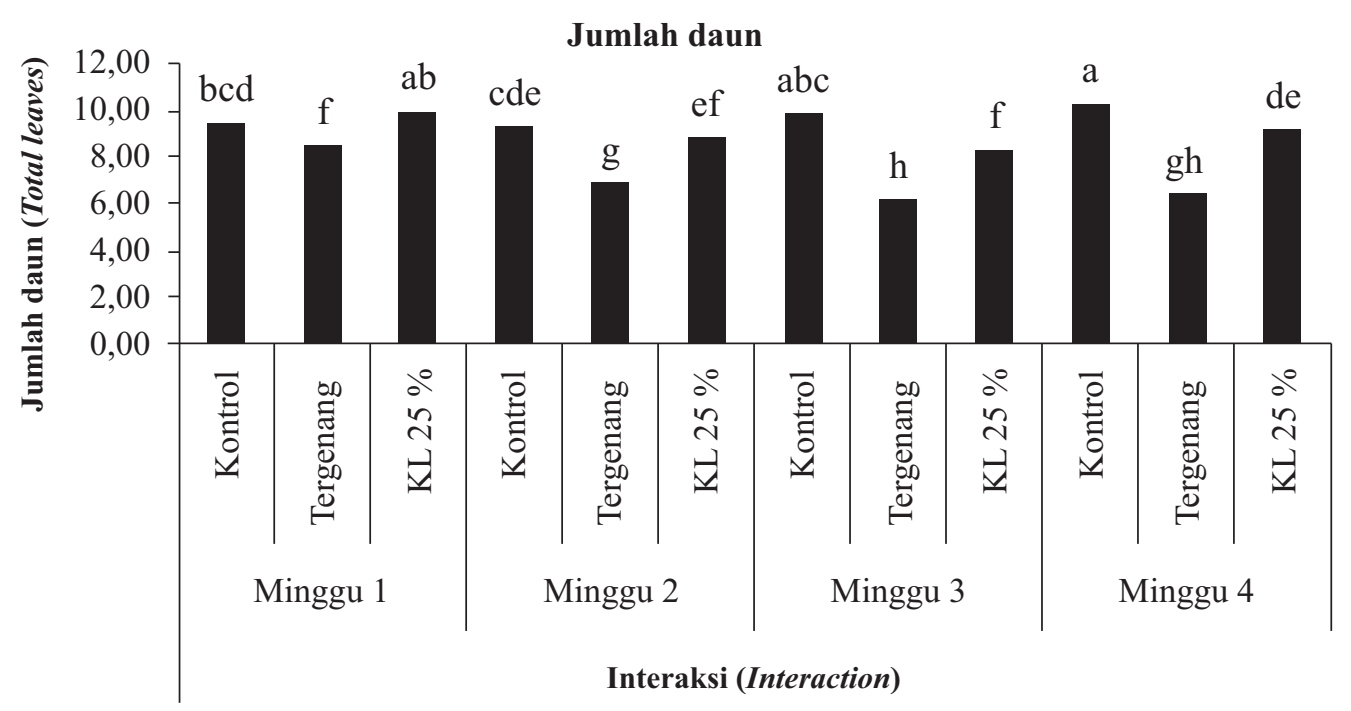

Sumber (Source): Diolah dari data lapang (Compiled and analyzed from field data)

Gambar(Figure) 2. Uji Duncan Jumlah daun berdasarkan interaksi antara waktu dan perlakuan (Duncan'test of total leaves based on interaction between time and treatment)

Persen tumbuh bibit pada minggu 1 , untuk semua perlakuan tidak berbeda nyata (Gambar 1). Namun persen tumbuh bibit mulai menurun akibat perlakuan cekaman pada minggu ke 3 (tiga) dan ke 4 (empat), terutama pada kondisi kekurangan air (KL $25 \%$ ). Jumlah daun, mulai berkurang akibat adanya cekaman terutama pada kondisi tergenang (Gambar 2), mulai minggu ke 2 (dua) hingga ke 4 (empat), hal ini ditunjukkan jumlah daun pada kondisi tergenang di minggu 2, 3 dan 4 tidak berbeda nyata. Jumlah daun yang berkurang berakibat pada turunnya persen tumbuh di minggu ke 3 dan 4 .

\section{Vigor bibit}

Variabel pengamatan lainnya yang diukur pada penelitian ini adalah kondisi vigor dari bibit, karena selain pertumbuhan, kondisi vigor bibit atau kekuatan bibit untuk tumbuh di lapangan sangat menentukan keberhasilan nantinya. Berdasarkan hasil analisis ragam seluruh respon vigor bibit tidak berbeda nyata, nilai rata-rata dari setiap respon vigor dapat dilihat pada Tabel 2 .

\section{Kandungan prolin dan serapan hara pada bibit}

Parameter lain yang diamati sebagai respon bibit terhadap cekaman adalah kandungan biokimia, yaitu kandungan prolin dan serapan hara $\mathrm{C}, \mathrm{N}, \mathrm{P}$ dan $\mathrm{K}$ oleh bibit. Hasil analisis ragam menunjukkan kandungan prolin serta serapan $\mathrm{C}$ dan $\mathrm{K}$ pada bibit tidak ada perbedaan yang nyata akibat perlakuan cekaman yang diberikan (Tabel 3).

Tabel(Table) 2. Nilai Rata-rata setiap respon pada berbagai kondisi cekaman (Average value of each response at several strees conditions)

\begin{tabular}{lcccc}
\hline \multirow{2}{*}{$\begin{array}{c}\text { Perlakuan } \\
\text { (Treatment) }\end{array}$} & \multicolumn{4}{c}{ Respon (Response) } \\
\cline { 2 - 5 } & KAR $(\%)$ & $\begin{array}{c}\text { Luas Daun } \\
\left(\mathrm{cm}^{2}\right)\end{array}$ & $\begin{array}{c}\text { LDS } \\
\left(\mathrm{m}^{2} / \mathrm{g}\right)\end{array}$ & RLD \\
\hline Genangan (Water logged) & 87,68 & 332,39 & 0,02 & 5,56 \\
KL 25\% (25\% water field capacity) & 92,67 & 395,83 & 0,03 & 5,95 \\
Kontrol (Control) & 88,07 & 338,21 & 0,02 & 7,34 \\
\hline
\end{tabular}

Sumber (Source): Diolah dari data lapang (Compiled and analyzed from field data)

Keterangan(Remarks): KAR (Kadar Air Relatif/ Relatif Water Moisture Content); Luas daun (Leaf area); LDS (luas Daun Spesifik/Spesific Leafarea); RLD (Ratio luas Daun/Leaf Area Ratio) 
Tabel (Table) 3. Nilai rata-rata kandungan Prolin, Karbon dan Kalium (Average value of Prolin, Carbon and Kalium compound)

\begin{tabular}{lccc}
\hline Perlakuan (Treament) & Prolin & Carbon (C) & Kalium (K) \\
\hline Kontrol (Control) & 315 & 20 & 0,14 \\
Genangan (Water logged) & 350 & 25 & 0,14 \\
KL 25\% (25\% water field capacity) & 389 & 27 & 0,21 \\
\hline
\end{tabular}

Sumber (Source) : Diolah dari data lapang (Compiled and analyzed from field data)

Namun serapan $\mathrm{N}$ dan P pada bibit bambang lanang memperlihatkan adanya perbedaan akibat perlakuan yang diberikan. Untuk mengetahui adanya keragaman pada serapan $\mathrm{N}$ dan $\mathrm{P}$, maka dapat dilihat dari hasil uji Lanjut Duncan(Tabel4).

\section{Jumlah dan ukuran stomata}

Jumlah atau kerapatan stomata tidak dipengaruhi oleh waktu pengamatan serta perlakuan cekaman, sedangkan diameter stomata dipengaruhi waktu pengamatan, namun tidak dipengaruhi oleh perlakuan cekaman. Adapun panjang stomata dipengaruhi oleh perlakuan cekaman.

Tabel (Table) 4. Hasil uji Duncan bobot N dan P (Duncan's test of $N$ and P compound)

\begin{tabular}{lcc}
\hline Perlakuan (Treatment) & Nitrogen $(\mathrm{N})$ & Fosfor $(\mathrm{P})$ \\
\hline Kontrol (Control) & $0,0467 \mathrm{a}$ & $0,0070 \mathrm{a}$ \\
Genangan (Water logged) & $0,0533 \mathrm{a}$ & $0,0080 \mathrm{a}$ \\
KL 25\% (25\% Water field capacity) & $0,0867 \mathrm{~b}$ & $0,0123 \mathrm{~b}$ \\
\hline
\end{tabular}

Sumber (Source) : Diolah dari data lapang (Compiled and analyzed from field data)

Keterangan (Remarks) : Nilai yang diikuti oleh huruf yang sama menunjukkan adanya perbedaan nyata pada tingkat 5\% (The value that followed by the same alphabet is different at 5\% level)

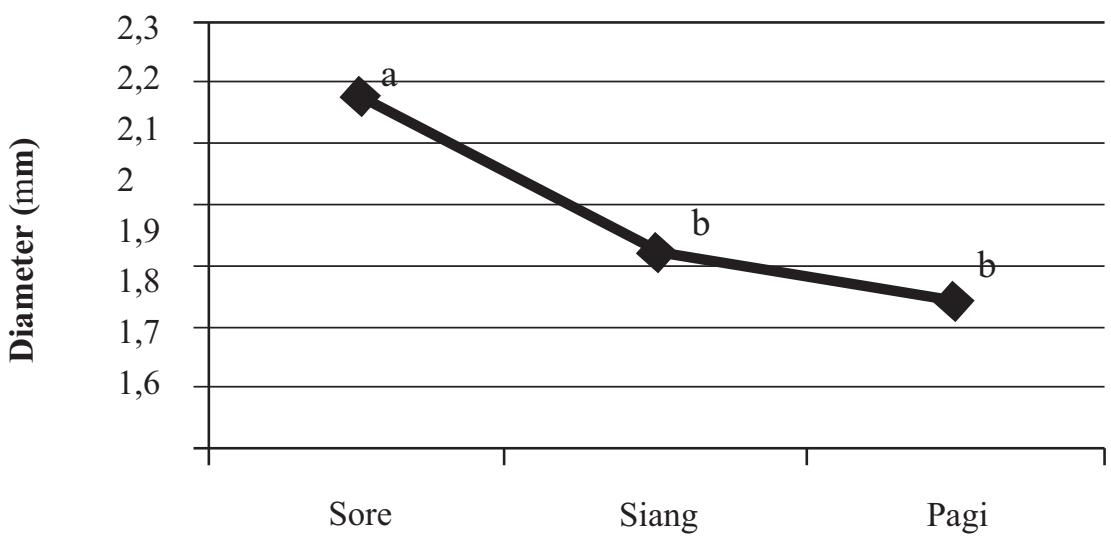

Waktu pengamatan

Sumber (Source): Diolah dari data lapang (Compiled and analyzed from field data)

Gambar(Figure)3. Hasil uji Duncan diameter stomata pada berbagai waktu pengamatan (Duncan's test of stomata diameter at several periods of time) 


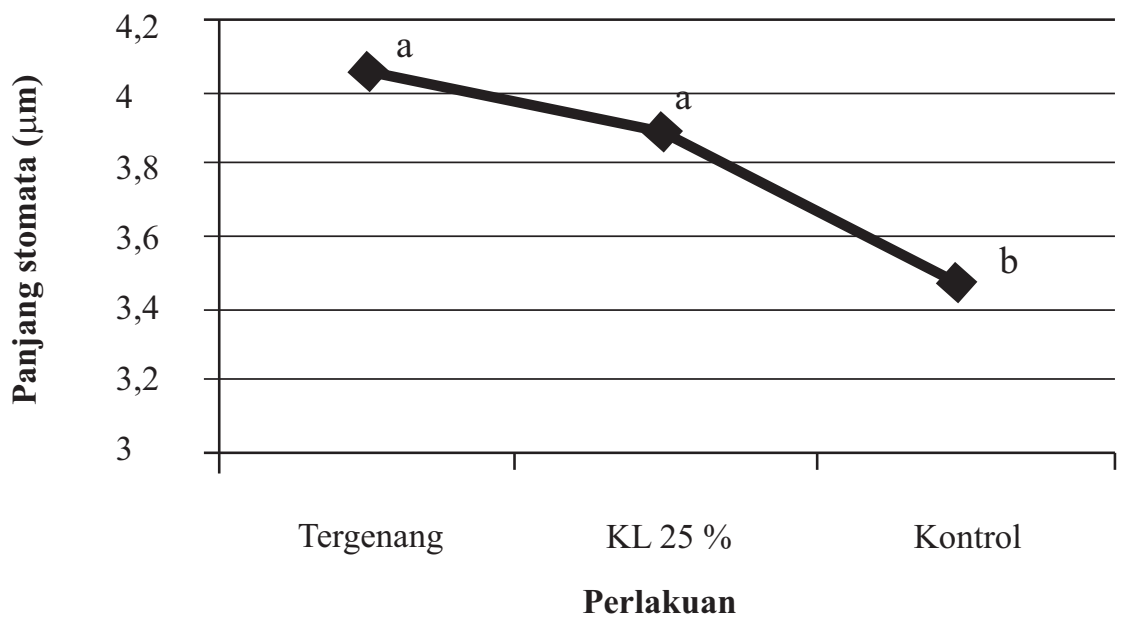

Sumber (Source): Diolah dari data lapang (Compiled and analyzed from field data)

Gambar(Figure) 4. Hasil uji Duncan panjang stomata pada kondisi cekaman (Duncan's test the length of stomata at several stress conditions)

Hasil uji lanjut untuk diameter menunjuk-kan bahwa diameter stomata waktu pengamatan sore hari berbeda nyata dengan pengamatan waktu siang dan pagi hari (Gambar 3). Panjang stomata pada tanaman yang selalu tergenang dan yang diberi perlakuan kekurangan air tidak berbeda nyata, tetapi terhadap kontrol berbeda nyata panjang stomatanya (Gambar 4).

\section{Nilai Indeks Sensitivitas (IS)}

Nilai indeks sensivitas (IS) untuk respon diameter, tinggi dan persen hidup bibit bambang lanang umur 4 (empat) minggu pada kondisi selalu tergenang dan kekeringan KL 25\% dapat dilihat pada Tabel 5 .

Tabel (Table) 5. Nilai Indeks Sensivitas (IS) diameter, tinggi dan persen hidup bibit pada kondisi KL 25\% dan Genangan (Index Sensivity (IS) of diameter, height and survival rate of seedling at stress condition)

\begin{tabular}{llcc}
\hline $\begin{array}{c}\text { Respon Pengamatan } \\
\text { (Response) }\end{array}$ & \multicolumn{1}{c}{$\begin{array}{c}\text { Kondisi } \\
\text { (Stress condition) }\end{array}$} & $\begin{array}{c}\text { Nilai IS } \\
\text { (IS Value })\end{array}$ & $\begin{array}{c}\text { Kategori } \\
\text { (Category) }\end{array}$ \\
\hline Diameter (Diametre) & KL 25\% & 1,089 & Peka \\
\cline { 2 - 4 } & Genangan & 1,155 & Peka \\
\hline Tinggi (Height) & KL 25\% & 0,984 & Agak Toleran \\
\cline { 2 - 4 } & Genangan & 1,036 & Peka \\
\hline Persen Hidup (Survival rate) & KL 25\% & 1,381 & Peka \\
\cline { 2 - 4 } & Genangan & 1,381 & Peka \\
\hline
\end{tabular}

Sumber (Source): Diolah dari data lapang (Compiled and analyzed from field data) 
Berdasarkan perhitungan nilai IS (Tabel 5), terlihat pertumbuhan diameter bibit peka terhadap adanya kondisi cekaman, nilai IS untuk pertumbuhan diameter berkisar antara 1,089-1,155, hal ini berarti nilai IS diameter untuk genangan dan kekeringan di atas 1 (IS > 1). Nilai IS untuk pertumbuhan tinggi pada kondisi kekeringan (KL $25 \%$ ) adalah 0,984 atau antara $0,5<\mathrm{IS}<1$, yang berarti agak toleran terhadap kekeringan, namun untuk genangan nilai IS $>1$ atau peka terhadap genangan. Persen hidup (\% hidup) bibit bambang lanang peka terhadap cekaman (Tabel 5), baik genangan ataupun kekeringan, karena nilai IS persen hidup sebesar 1,381 yang berarti persen hidup bibit sampai umur 4 (empat) minggu sangat peka terhadap adanya cekaman.

Nilai IS yang diperoleh tersebut berkaitan dengan hasil analisis ragam yang telah dilakukan, yang menunjukkan bahwa respon diameter dan persen tumbuh sangat dipengaruhi oleh kondisi cekaman yang diberikan serta waktu, dan ini terlihat dari nilai IS, yang memperlihatkan bahwa kedua respon tersebut peka terhadap adanya perlakuan genangan maupun KL $25 \%$. Nilai IS tertinggi adalah pada persen hidup, yang berarti bibit bambang lanang sangat peka terhadap adanya cekaman, sehingga menyebabkan kematian padabibit.

\section{B. Pembahasan}

Kondisi pertumbuhan serta persentase hidup tanaman pada kondisi kekeringan atau selalu tergenang, dapat menjadi salah satu indikator penting untuk mengetahui tingkat toleransi tanaman terhadap kondisi cekaman air (Vreugdenhil et al., 2006; Mommer et al., 2006; Li et al., 2011). Persentase hidup bibit dan pertumbuhan bibit pada perlakuan bibit dengan selalu dalam kondisi tergenang dan bibit dengan penyiraman 25\% kapasitas lapang dan bibit dengan kondisi optimal, menunjukkan adanya perbedaan yang nyata dalam persentase hidup, tinggi, diameter dan jumlah daun (Tabel 1). Terjadi penurunan persen hidup yang cukup cepat pada bibit berumur 3 (tiga) minggu setelah perlakuan genangan dan kekeringan. Bibit bambang lanang pada kondisi perlakuan KL 25\% daun sebagian menjadi layu dan berwarna cokelat lalu mengering, demikian pula pada kondisi tergenang daun sebagian menguning dan kecokelatan serta layu. Proses ini umum terjadi pada tanaman yang mengalami gejala kekeringan atau kekurangan air bagi proses metabolismanya.
Hasil penelitian pada bibit bambang lanang, dengan perlakuan KL 25\% dan genangan mengakibatkan beberapa tanaman mengalami kematian, yang dimulai dengan gejala layu pada batang serta warna daun yang berubah cokelat. Namun tidak semua tanaman mengalami hal ini, pada penelitian jenis jabon merah (Yulianti et al., 2012) pada perlakuan tergenang, bibit jabon merah mampu beradaptasi dengan baik dengan tidak terhambatnya pertumbuhan bibit. Demikian pula yang dilaporkan oleh Sudrajat et al. (2015) pada tanaman jabon putih, jenis ini lebih toleran pada kondisi tergenang dibandingkan pada kondisi kekurangan air. Bentuk-bentuk adaptasi tersebut merupakan bentuk adaptasi tanaman agar dapat bertahan terhadap kondisi genangan dan kekeringan. Menurut Nguyen et al., 1997 dalam Lestari (2006), dikatakan bahwa terdapat berbagai mekanisme toleransi pada tanaman sebagai respon adanya cekaman kekeringan salah satunya adalah dengan memperpendek siklus tumbuh.

Persen hidup bibit bambang lanang sangat dipengaruhi oleh ketersediaan air, bibit akan mengalami kelayuan apabila kekurangan air demikian pula apabila dalam kondisi tergenang. Hal ini berarti bahwa ketersediaan air mutlak diperlukan bagi pertumbuhan anakan bambang lanang, pernyataan ini didukung oleh hasil penelitian Soetrisno (1996), serta hasil penelitian Leiwakabessy (1998) dalam Soetrisno (1996) yang menyatakan bahwa pertumbuhan tanaman berbanding lurus dengan jumlah air yang tersedia, sampai suatu batas tertentu. Pada saat pasokan air tidak mencukupi kebutuhan evapotranspirasi (tanaman mengalami stress air), transpirasi dan asimilasi cenderung mulai menurun Blum (1996) dalam Lapanjang et al., (2008). Selain itu hal tersebut menyebabkan hilangnya turgiditas dan suplai air yang kecil sehingga menurunkan metabolisme akar dan pengambilan $\mathrm{CO}_{2}$ oleh daun serta penyerapan hara dan mineral tanah sehingga pertumbuhan pun terhambat, sedangkan pada perlakuan tergenang mengakibatkan terhambatnya sistem transport yang terjadi di dalam tubuh bibit dan sistem perakaran terganggu karena kurangnya pasokan $\mathrm{O}_{2}$

Selain persentase hidup, tinggi dan diameter, kondisi cekaman juga berpengaruh kepada jumlah daun bibit bambang lanang. Variabel ini cukup penting untuk menunjang pertumbuhan bibit yang ideal, karena daun merupakan tempat berlangsungnya fotosintesa, yaitu proses pembuatan cadangan makanan untuk pertumbuhan. Apabila 
jumlah daun berkurang, maka akan menurunkan total luas permukaan daun, sehingga akan mengakibatkan menurun pula proses fotosintesa serta cadangan makanan yang terbentuk akan menurun pula. Dan hal ini akan menyebabkan terganggunya pertumbuhan dan metabolisme lainnya (Rucker et al., 1995), sehingga dapat berujung pada kematian. Secara umum tanaman dalam keadaan cekaman kekeringan memiliki luas daun dan ratio berat daun yang lebih rendah dibanding yang tidak mengalami cekaman (Purwanto, 2003).

Respon lain yang dapat dijadikan indikator dalam menduga tingkat toleransi tanaman terhadap kondisi cekaman adalah KAR daun, tanaman toleran akan memiliki nilai KAR relatif lebih tinggi dibandingkan dengan tanaman yang peka terhadap cekaman kekeringan. Semakin rendah nilai KAR menunjukkan tanaman tersebut mengalami cekaman kekeringan yang tinggi. Namun nilai KAR bibit bambang lanang menunjukkan tidak berbeda nyata antar perlakuan, hal ini berarti perlakuan KL 25\% dan genangan tidak menyebabkan terjadinya penurunan nilai KAR sampai bibit berumur 4 (empat) minggu.

Disamping perubahan ciri fisik, untuk mengetahui respon cekaman terhadap bibit bambang lanang dapat dilakukan melalui analisis kandungan biokimia, dalam hal ini adalah kandungan prolin. Menurut Simpson (2001) dikatakan bahwa Prolin merupakan asam amino bebas yang disintesis tanaman dalam jaringan floem, akar dan biji. Prolin merupakan asam amino paling stabil dan paling sedikit menghambat pertumbuhan tanaman dibandingkan asam amino lainnya (Levitt, 1980). Pada kondisi cekaman kekeringan dan berbagai cekaman osmotik lainnya, beberapa tanaman memiliki mekanisme adaptasi berupa kemampuan untuk mensintesis senyawa osmoprotektan atau larutan yang sesuai (Ronde et al., 2000). Tanaman yang terkena cekaman kekeringan akan meng-akumulasi asam amino prolin dalam jumlah tertentu dan bervariasi bergantung pada jenis tanaman, varietas dan umur tanaman yang digunakan (Hamim, 2004). Kandungan prolin pada bibit bambang lanang tidak berbeda nyata akibat perlakuan yang diterapkan, namun dari nilai rata-rata (Tabel 3) terlihat kandungan prolin pada bibit yang diberi perlakuan kekeringan (KL 25\%) mempunyai nilai tertinggi yaitu 38,936 . Hal ini menunjukkan adanya peningkatan akumulasi prolin akibat perlakuan kekeringan. Demikian pula pada kondisi genangan nilai kandungan prolin lebih tinggi $(34,9633)$ dibanding kontrol $(31,5033)$ namun masih lebih rendah dari KL $25 \%$.
Terdapat dua mekanisme toleransi pada tanaman sebagai respon adanya cekaman kekeringan yaitu (1) peningkatan akumulasi senyawa tertentu seperti prolin yang bertindak sebagai osmotic adjustment, dan (2) mengoptimalkan peranan stomata untuk mencegah hilangnya air melalui daun (Nguyen et al., 1997). Fungsi dari osmotic adjustment adalah mempertahankan berlangsungnya proses pertumbuhan dan stomata tetap membuka.

Peran stomata dalam tanaman sangatlah penting, melalui stomata pengaturan keluar masuknya air dan gas dapat dikontrol, sehingga dapat digunakan sebagai alat untuk adaptasi tanaman terhadap cekaman kekeringan. Pada kondisi cekaman kekeringan stomata akan menutup sebagai upaya untuk menahan laju transpirasi (Lestari, 2006). Beberapa tanaman beradaptasi terhadap cekaman kekeringan dengan cara mengurangi ukuran stomata dan jumlah stomata (Price \& Courtois, 1991). Kerapatan stomata mempengaruhi dua proses penting yaitu fotosintesis dan transpirasi.

Pengamatan jumlah dan ukuran stomata pada bibit bambang lanang dilakukan pada tiga waktu yang berbeda yaitu pagi hari, tengah hari dan sore hari. Hasil pengamatan menunjukkan jumlah stomata pada ketiga perlakuan (kontrol, selalu tergenang dan KL $25 \%$ ) tidak berbeda nyata, hal ini berarti hingga umur 4 minggu pengamatan belum terlihat adanya mekanisme toleransi terhadap cekaman yang diperlihatkan oleh adanya penurunan jumlah stomata. Namun hasil ini sesuai dengan hasil penelitian Miskin et al. (1992) yang menyatakan bahwa kerapatan stomata yang tidak berbeda pada tanaman yang tumbuh di dalam lingkungan yang berbeda.

Perubahan karakter stomata dipengaruhi oleh faktor lingkungan dimana tanaman tersebut tumbuh, namun karakter genetis stomata merupakan faktor internal yang mempengaruhi tingkat adaptasi tanaman terhadap kondisi cekaman. Karakter genetis stomata yang menentukan tingkat adaptasi tanaman terhadap lingkungan kering adalah kerapatan stomata yang rendah serta ukuran stomata yang lebih kecil. Secara umum tanaman yang dianggap tahan terhadap cekaman kekeringan mempunyai kerapatan stomata (per $\mathrm{mm}^{2}$ ) lebih rendah dan menjadi berkurang ukuran panjang dan lebarnya (diameter). Hal ini sesuai dengan hasil penelitian Lestari (2005) pada padi varietas Towuti yaitu adanya hubungan antara tanaman yang tahan terhadap kekeringan dengan kerapatan stomata yang rendah. Namun untuk ukuran stomata (panjang dan lebar/diameter) 
tampaknya tidak ada penurunan ukuran yang nyata karena pada umumnya stomata menjadi lebih panjang atau menjadi lebih lebar.

Tingkat kemampuan bibit beradaptasi terhadap kondisi kekurangan air atau selalu tergenang dapat dilihat berdasarkan hasil perhitungan nilai Indeks Sensivitas (IS). Nilai IS untuk pertumbuhan diameter dan persen hidup pada kondisi genangan ataupun kekeringan pada bibit adalah di atas 1 (IS > 1), berarti kedua variabel ini peka terhadap kondisi kekeringan maupun genangan, dan hal ini sesuai dengan hasil analisis ragam, sedangkan pertumbuhan tinggi bibit pada kondisi KL $25 \%$ mempunyai nilai 0,98 (IS = 0,98 ) yang berarti tanaman bibit bambang lanang agak toleran terhadap kekeringan untuk pertumbuhan tinggi. Hasil penelitian ini menunjukkan kemampuan bibit bambang lanang untuk tumbuh pada lahan dengan kondisi kekurangan air atau selalu tergenang sangat rendah. Informasi ini sangat penting, karena menurut Ky-Dembele et al. (2010) dikatakan bahwa keberhasilan penanaman secara luas suatu tanaman sangat ditentukan oleh keberhasilan dalam menseleksi jenis-jenis yang mampu bertahan pada kondisi kekeringan maupun selalu tergenang air.

\section{KESIMPULAN DAN SARAN}

Bibit bambang lanang (Michelia champaka L.) mempunyai kecenderungan peka terhadap cekaman kekeringan maupun genangan, perlakuan cekaman menurunkan persen tumbuh bibit sejak minggu ke-3 (tiga) setelah perlakuan dengan nilai Indeks Sensitivitas (IS) untuk pertumbuhan diameter dan persen tumbuh lebih dari 1 (IS $>1$ ).

\section{UCAPAN TERIMA KASIH}

Ucapan terima kasih disampaikan kepada semua pihak, khususnya kepada Bapak Suherman dan Bapak Abay, teknisi yang telah membantu sejak pengumpulan bahan penelitian di lapangan hingga pelaksanaan penelitian di laboratorium.

\section{DAFTAR PUSTAKA}

Blum, A., (1997). Crop responses to drought and the interpretation of adaptation. In: Belhassen, J.(Ed.), Drought tolerance in higher plants: genetical, physiological and molecular biological analysis (pp. 57-70). Dordrecht: Kluwer Academic Publications.
Cernusak, L.A., Aranda, J., Marshall, J.D., \& Winter, K. (2006). Large variation in whole-plant water-use efficiency among tropical tree species. New Phytologist, 173, 294-305. DOI 10.1111/j.14698137.2006.01913.x.

Cordeiro, Y.E.M., Pinheiro, H.A., dos Santos-Filho, B.G., Correa, S.S., Silva, J.R.R., \& Dias-Filho MB. (2009). Physiological and morphological responses of young mahogany (Swietenia macrophylla King) plants to drought. Forest Ecology and Management, 258, 1449-1455. DOI : 10.1016/j.foreco.2009.06.054.

Ditmarova, L., Kurjak, D., Palmroth, S., Kmet, J., Strelcova, K. (2010). Physiological responses of Norway spruce (Picea abies) seedlings to drought stress. Tree Physiology, 30, 205-213. DOI:10.1093/treephys/tpp116.

Djazuli, M. (2010). Pengaruh cekaman kekeringan terhadap pertumbuhan dan beberapa karakter morfo-fisiologis Tanaman Nilam. Buletin Littro, 21(1), 8-17.

Hemon, A.F. (2009). Pertumbuhan tanaman kacang tanah hasil seleksi in vitro pada media polietilina glikol terhadap cekaman larutan polietilina glikol.Crop. Agro, 2(1), 1-7.

Kunarso, A., \& Siahaan, H. (2008). Pemetaan sebaran pohon induk jenis prioritas Sumatera Selatan. Info Hutan, 5(1), 35-43.

Ky-Dembele, C., Bayala, J., Savadogo, P., Tigabu, M., Odén, P.C., Boussim, I.J. (2010). Comparison of growth responses of Khaya senegalensis seedlings and stecklings to four irrigation regimes. Silva Fennica, 44(5), 787-798.

Lapanjang, Iskandar, Purwoko, B.S., Hariyadi, Wilarso, S., Budi, R., \& Melati, M. (2008). Evaluasi beberapa ekotipe jarak pagar (Jatropa curcas L.) untuk toleransi cekaman kekeringan. Bul. Agron., 36(3), 263-269.

Lestari, E.G. (2006). Hubungan antara kerapatan stomata dengan ketahanan kekeringan pada somklon padi Gajahmungkur, Towuti dan IR 64. Biodiversitas, 7(1), 44-48.

Li, F.L., Bao, W.K., \& Wu, N. (2011). Morphological, anatomical and physiological responses of Campylotropis polyantha (Franch.) Schindl. seedlings to progressive water stress. Scientia Horticulturae,127, 436-443. DOI: 10.1016/ j.scienta.2010.10.017.

Mommer, M., Lenssen, J.P.M., Huber, H., Visser, E.J.W., \& Kroon, H.D. (2006). Ecophysiological determinants of plants performance under flooding: a comparative study of seven plant families. Journal of Ecology, 94(6), 11171129. 
Orwa, C., Mutua, A., Kindt, R., Jamnadass, R., \& Simons, A. (2009). Agroforestree Database: a tree reference and selection guide version 4.0 Akses dari: http://www.worldagroforestry.org/ $\mathrm{af} / \mathrm{treedb} /$.

Purwanto, E. (2003). Photosynthesis Activity Of Soybean (Glycine Max L.) Under Drought Stress . Agrosains, 5(1).

Rucker, K.S., Kevin, C.K., Holbrook, C.C., \& Hook, J.E. (1995). Identification of peanut genotypes with improved drought avoidance traits. Peanut Sci., 22, 14-18.

Sinaga, R. (2007). Analisis model ketahanan rumput gajah dan rumput raja akibat cekaman kekeringan berdasarkan respons anatomi akar dan daun. Jurnal Biologi Sumatera, (2)1, 1720 .

Nio, S.A., Tondais, S.M., \& Butar, R.B. (2010). Evaluasi Indikator Toleransi Cekaman Kekeringan pada Fase Perkecam-bahan Padi (Oryza sativa L.). Jurnal Biologi, 14(2), 50-54.

Sudrajat, D.J., Siregar, I.Z., Khumaida, N., Siregar, U.J., Mansur, I. (2015). Adaptability of white jabon (Anthocephalus cadamba Miq.) seedling from 12 populations to drought and waterlogging. Agrivita Journal of Agriculture Science, 37(2), 130-143.

Suharno, Mawardi, I., Setiabudi, Lunga, N., \& Tjitrosemito. (2007). Efisiensi penggunaan nitrogen pada tipe vegetasi yang berbeda di
Stasiun Penelitian Cikaniki, Taman Nasional Gunung Halimun Salak, Jawa Barat. Biodiversitas, 8(4), 287-294.

Sulistyowati, E. (2009). Pemanfaatan Teknologi Transgenik Untuk Perakitan Varietas Unggul Kapas Tahan Kekeringan. Perspektif, 8(2), 96107.

Vreugdenhil, S.J., Kramer, K., \& Pelsma, T. (2006). Effects of flooding duration, frequency and depth on the presence of saplings of six woody species in north-west Europe. Forest Ecol. Manag., 236, 47-55.

Xiaoling, L., Ning, L., Jin, Y., Fuzhou, Y., Faju, Y., \& Fangqing, C. (2011). Morphological and photosynthetic responses of riparian plant Distylium chinense seedlings to simulated autumn and winter flooding in three Gorges Reservoir Region of the Yangtze River, China. Acta Ecologica Sinica, 31, 31-39.

Yang, F., \& Miao, L.F. (2010). Adaptive responses to progressive drought stress in two poplar species originating from different altitudes. Silva Fennica, 44(1), 23-37.

Yulianti, Rustam, E.Y., \& Sudrajat, D.J. (2012). Kajian ekologi dan biologi benih dan bibit jabon putih (Anthocephalus cadamba) dan jabon merah (Anthocephalus macrophyllus). Laporan Hasil Penelitian. Bogor: Balai Penelitian Teknologi Perbenihan Tanaman Hutan Bogor. 